\title{
TRANSFORMATIVE POETRY. A CASE STUDY OF W. H. AUDEN'S MUSÉE DES BEAUX ARTS AND GENERAL CONCLUSIONS
}

\author{
MARCEL SAROT ${ }^{*}$ \\ Tilburg University
}

\begin{abstract}
This article situates Auden's poem Musée des Beaux Arts in the process of his conversion to Christianity. The author argues for the layered intertextuality of the poem, in which allusions to Bruegel's Landscape with the Fall of Icarus, The Census at Jerusalem, and The Massacre of the Innocents can be recognised. Moreover, Philippe de Champaigne's Presentation in the Temple and Peter Paul Rubens's The Martyrdom of St Livinus (in the same museum in Brussels) seem also to have influenced the poem. Finally, there is reason to suppose that John Singer Sargent's Crashed Aeroplane influenced Auden. In an analysis of the structure of the poem, the author argues that there is a clear structure hidden under the surface of day-to-day language. He connects this hidden structure with Auden's poem The Hidden Law, and suggests that Auden wished to claim that even though we cannot understand suffering, it has a hidden meaning known only to God. This hidden meaning connects our suffering with the self-emptying of Christ, a connection which the author demonstrates is in fact also made in Musée des Beaux Arts.
\end{abstract}

KEY WORDS: Wystan Hugh Auden, Pieter Bruegel the Elder, theology, theology and literature, suffering

In his well-known textbook on the problem of evil, Mark Larrimore includes a poem by Wystan Hugh Auden, Musée des Beaux Arts. He introduces the poem with just this line: 'the famous poem by the Catholic ${ }^{1}$ English poet W. H. Auden (1907-1973), composed as Europe headed toward war in September 1938, is one of several poems which explore the world's indifference to and unwillingness to recognize suffering' (Larrimore 2001: 327). That is indeed one of the poem's themes, but I knew even after a first reading that there was more to it than that. When I began to use Larrimore's book in class, I started to analyse this poem with my students. The insights that emerged from this form the basis for this contribution. It is at first sight an enigmatic poem:

* MARCEL SAROT (PhD 1992, University of Utrecht) is dean and professor of fundamental theology at the School of Catholic Theology within Tilburg University. Email: m.sarot@tilburguniversity.edu.

1 'Catholic' does not mean Roman Catholic here, but tending towards the Catholic. Auden frequented an Episcopal church since 1940. 
Musée des Beaux Arts

1 About suffering they were never wrong,

2 The Old Masters; how well they understood

3 Its human position; how it takes place

4 While someone else is eating or opening a window or just walking dully along;

5 How, when the aged are reverently, passionately waiting

$6 \quad$ For the miraculous birth, there always must be

7 Children who did not specially want it to happen, skating

8 On a pond at the edge of the wood:

9 They never forgot

10 That even the dreadful martyrdom must run its course

11 Anyhow in a corner, some untidy spot

12 Where the dogs go on with their doggy life and the torturer's horse

13 Scratches its innocent behind on a tree.

14 In Breughel's Icarus, for instance: how everything turns away

15 Quite leisurely from the disaster; the ploughman may

16 Have heard the splash, the forsaken cry,

17 But for him it was not an important failure; the sun shone

18 As it had to on the white legs disappearing into the green

19 Water; and the expensive delicate ship that must have seen

20 Something amazing, a boy falling out of the sky,

21 Had somewhere to get to and sailed calmly on.

(Mendelson \& Auden 1979: 79-80)

\section{Historical Context}

Auden wrote Musée des Beaux Arts in December 1938 (Mendelson 1981: 346348.362-364) after visiting the museum then called the Musée Royal des BeauxArts in Brussels. Auden was not a connoisseur of painting nor a dedicated visitor of museums. His bad eyesight probably impeded full enjoyment of the visual arts (Hecht 1993: 98), and the occasion of Auden's visit to the museum was therefore more prosaic. The winter of 1938 was bitterly cold, and when the heating broke down in the apartment where Auden was staying with his friend Christopher Isherwood, he spent the day looking for a heated space to spend the time, such as the Royal Museum of Fine Arts (De Volder 4-5). He was struck there by Pieter Bruegel's painting Landscape with the Fall of Icarus. It inspired him to write his only poem dedicated to a specific painting (Hecht 1993: 98). [See Appendix 1-Bruegel, Landscape with the Fall of Icarus]

The painting in question is called 'Breughel's Icarus' (line 14) in the poem. The catalogue of the museum ascribes it to Pieter Bruegel the Elder, and gives it the title of The Fall of Icarus (Robert-Jones 1974), but it is often called Landscape with the Fall of Icarus. Why this is so becomes evident as soon as you look at the painting. At first sight, it appears to be an idyllic landscape with a 
ploughman, and a shepherd in the background; even further in the background there is the sea with several ships. There is nothing tragic about the painting, and even if you notice the two legs sticking out of the water to the right of the ship at the front, you might be inclined to think someone was simply taking a refreshing dip. There is nothing to show that it is Icarus, and that he is about to die. The painting gives a very different-less dramaticportrayal of the mythological story of Daedalus and Icarus than we are used to. Let me summarise the story briefly. Daedalus and his son Icarus flee the island of Crete to avoid the ire of King Minos. Daedalus makes wings from birds' feathers for the two of them, using wax as glue. Icarus must not fly too low, because then his wings will get wet and he will crash, but not too high either, because then the wax will melt, the feathers will become unstuck and he will crash too. Icarus is overconfident and flies too high; as a result, he falls from the sky and drowns, and his father arrives in Sicily alone. The story lends itself perfectly to dramatic representation. In Rubens' Fall of Icarus, for instance, in the same Brussels museum, Icarus can be seen falling helplessly, while his father, diagonally above him, looks on, unable to prevent the disaster.

Auden must have seen more paintings during his visit to the museum, and it is often assumed that lines 5-13 are allusions to other paintings; I will return to this issue later, because it does not belong to the historical context.

I would now like to address two further developments in Auden's life: his witnessing of the Second Sino-Japanese War in the first half of 1938, and his relationship to Christianity. The famous American art historian Alexander Nemerov has pointed out the importance of Auden's visit to China. Auden wrote a book about this visit, in which he combines poetry and journalism (Auden 1939). Nemerov has convincingly argued on the basis of a number of parallels that the American painter John Singer Sargent (1856-1925) modelled his 1918 painting Crashed Aeroplane, which depicts an airplane shot out of the sky during the First World War, on Bruegel's painting (Nemerov 2005: 708-710). [See Appendix 2-John Singer Sargent, Crashed Aeroplane]

Nemerov has thus shown that the association between Bruegel's painting and aerial battle predated Auden's work. That Auden was fascinated by aerial battles is evident from his descriptions and photos in Journey to a War. In China, Auden actually saw young men floating from the sky after their planes had been shot down; thankfully their fall was broken by their parachute. Nemerov has suggested that these experiences may well have drawn Auden's attention to Bruegel's Icarus and caused him to capture the hidden drama of this image in words (Nemerov 2005: 784-789).

As far as Auden's relationship to Christianity is concerned: Auden lost his faith in the early 1920s when he was at boarding school (Kirsch 2005: xiii, 6 7; Davenport-Hines 2004: 16). However, in the year 1933 he had a mystical 
experience that revealed to him the meaning of the Christian exhortation to love one's neighbour as oneself (Kirsch 2005: 10-14; Davenport-Hines 2004: 18). In October 1940-he had moved to New York in the meantime-he began to attend an Episcopal church, and from that moment on he became a Christian poet (Davenport-Hines 2004: 20; Jenkins 2004: 47; Kirsch 2005: xiii), although his Christianity always retained a somewhat unorthodox character, inspired as it was by Charles Williams, Sören Kierkegaard, Reinhold Niebuhr (Smith 2004: 8), and Dietrich Bonhoeffer (Mendelson 2004: 62).

Unorthodox perhaps it was, but nonetheless central to his thinking and writing for that. In 1941 he criticised the 'cultured people, to whom [...] theological terms were far more shocking than any of the four-letter words' in a review, and the Christian faith and theological reflection on it became driving forces in his own work from that time on (Kirsch 2005: xiii-xiv et passim). Although Musée des Beaux Arts precedes Auden's formal return to Christianity in 1940 , it is often read as part of a gradual process leading towards Christianity (Kirsch 2005: xiii, 18-20). Gareth Reeves has therefore called it a 'proleptically Christian poem' (Reeves 2004: 194), a poem that anticipates his conversion to Christianity.

\section{Layered References: Intertextual Analysis}

There is no getting away from intertextual analysis when it comes to Musée des Beaux Arts. Intertextuality-a term which was formed by analogy to the word 'intersubjectivity'-denotes the phenomenon that every text stands in relation to other 'texts': by quoting, referencing, reprising themes, et cetera. In this sense, texts are mosaics, which engage in dialogue with other 'texts'. I am putting the word 'texts' between inverted commas, because intertextuality occurs not only between texts, but also between texts and other forms of art (Jack 2012: 52-71).

There is no avoiding intertextual analysis of Auden's poem, because it is an instance of strong intertextuality: an explicit dialogue with paintings that are directly relevant to the interpretation of Auden's poem, and which transforms the meaning of those paintings. One of these paintings is mentioned explicitly, as is the museum where Auden saw the paintings (in the title of the poem). We have already seen that it is quite possible that the poem also alludes to other paintings, such as Sargent's Crashed Aeroplane. I should add here that an intertextual analysis of a poem like Auden's is in principle a limitless exercise; one quotation almost automatically leads to another allusion, and ultimately the entire cultural context is relevant. In this sense, the poem is as boundless as reality itself. I will therefore have to limit myself to those interactions with other 'texts' that are most relevant to the interpretation of the poem.

PERICHORESIS 14.2 (2016) 
The painting that is mentioned explicitly is Bruegel's Landscape with the Fall of Icarus. If we assume that this painting is indeed by Bruegel, then the version that hangs in the Museum Van Buuren, also in Brussels, is a copy. It is also painted on wood, but wood cut after Bruegel's death. What appears to have struck Auden most in this painting was the fact that no one in the drowning young man' surroundings appears to take any notice at all of the tragedy. The ploughman continues to plough, the ship sails on, the shepherd looks in the other direction. This rendering of the fall of Icarus is so untypical, that we may well ask whether this story is actually still the subject of the painting. This question becomes all the more acute when we realise that the sun in the painting is not high in the sky, but low on the horizon: it rises from the water. This is not consonant with the myth of Icarus, who fell because he flew too high, and therefore came too close to the sun.

There are indications in the painting, however, that confirm that it is indeed a depiction of the fall of Icarus. They can be discovered by comparing Bruegel's painting with Ovid's account of the story of Daedalus and Icarus (Ovid VIII: 183-253). Ovid mentions three spectators to the disaster: a fisherman with a rod, a shepherd with a stick, and a ploughman. All three appear in Bruegel's painting. This cannot be a coincidence, even if the shepherd looks in the wrong direction, the ploughman does not look up at all, and the fisherman seems oblivious to what is going on, even though from his position he should be able to see Icarus. Furthermore, there is a partridge in the bottom right of the painting, sitting on a branch to the left above the fisherman. The partridge also appears in Ovid: Daedalus killed his sister's son out of jealousy. The gods transformed him into a partridge, so that Daedalus' victim is now a witness to the revenge of the gods in the form of the fall of Daedalus' son Icarus (cf. Van Roy). [See Appendix 3-Pieter Bruegel, Landscape with the Fall of Icarus (Musée Van Buuren)]

A second series of indications that Bruegel did in fact depict the fall of Icarus becomes evident when we include the Museum Van Buuren's copy of Bruegel's painting in our analysis. In this copy, the sun stands high in the sky. This must also have been the original position of the sun in the more famous painting, if only because the ploughman's shadow would otherwise have had to be much longer. Moreover, the Museum Van Buuren's copy also includes Daedalus, and in such a position that it becomes clear what the shepherd is looking at: at Daedalus who is flying past. There is therefore much to be said for the idea that the Museum Van Buuren's version is the more authentic image-and incidentally its colours are more authentic too, as the gold colour in the more famous version was caused by discolouring of the varnish (McCouat 2015). But how can a copy be more authentic than the original? If the more famous picture is indeed the original—and this is still 
controversial-then its history is very complex. Technical research has revealed that the image was probably painted on wood and was later transferred onto canvas. In the process—or on some other occasion-the original paint layer was seriously damaged, which made it necessary to repaint parts of the painting (Anonymous 2016). A restorer who lacked proper understanding of the image may then have painted over whatever was left of Daedalus (dark patches), and may have put the sun in the wrong place. The irony of this history is that the mutilated version without Daedalus looks both more modern and more mysterious, and that it was the version that so moved Auden. And Auden's interpretation has subsequently strongly influenced the interpretation of the painting, to such a degree in fact that it has impacted on the way the question of the original image was answered (McCouat 2015).

It is inevitable in this intertextual analysis that we should pay some attention to the first thirteen lines of Auden's poem. At the time of Auden's visit to the museum, Bruegel's Landscape with the Fall of Icarus hung in a special alcove dedicated to Bruegel (Kinney 1963: 529). Since Arthur Kinney's classic article from 1963, the accepted view has been that lines 5-13 contain references to two of the three other paintings in this alcove. The Census at Bethlehem supposedly inspired the "children who did not specially want it to happen, skating / On a pond at the edge of the wood'. A difficulty is that, although this painting does show children skating on a pond, the pond is not located at the edge of a wood. Kinney did not notice this. This difficulty is not insurmountable, however, when we realise that human memory does not store images in the same way computers do; the human mind does not store copies (Epstein 2016). [See Appendix 4-Pieter Bruegel, The Census at Bethlehem]

If The Census at Bethlehem is indeed the source of this scene, then this also provides the context for a number of other phrases from the poem. Joseph and a heavily pregnant Mary occupy centre stage in this picture, as they arrive in Bethlehem for the census called by the Emperor Augustus. This means that the miraculous birth in the poem is the birth of Jesus. Nor is it difficult in this case to identify 'the aged [who] are reverently, passionately waiting / For the miraculous birth': this must be Anna and Simeon (Luke 2:22-40). It would also explain why Auden writes that the children did not specially want the birth of Jesus to happen: even if they themselves were older than two, and would not personally fall victim to the massacre of the innocents in Bethlehem (Matthew 2:16), they would at least lose their younger brothers. It is precisely this event which is depicted in the second painting to which Auden was said to have alluded: The Massacre of the Innocents. [See Appendix 5Bruegel, The Massacre of the Innocents]

This painting would be able to explain the phrases 'that even the dreadful martyrdom must run its course / Anyhow in a corner, some untidy spot / Where the dogs go on with their doggy life and the torturer's horse / 
Scratches its innocent behind on a tree'. It does indeed depict dreadful martyrdom, and the painting also contains a number of dogs going about their business. There are even horses, although none of them is scratching its behind on a tree (Kinney 1963). This again could be explained through the way human memory works (Epstein 2016).

Kinney and others assume that Auden was referring only to paintings by Bruegel $^{2}$, but I do not see that this must necessarily be the case. If he did indeed spend considerable time in the museum because the heating at home was broken, would he really only have looked at paintings by Bruegel? And if not, why would he then only allude to these paintings and not to others? The poem itself contains no indication that this was the case. The Old Masters is plural, and I think there are good grounds to take Auden at his word here. He could perhaps also have been thinking of Philippe de Champaigne's The Presentation in the Temple (1648), which places Anna and Simeon centre stage (cf. De Geest 2006: 112). And at a stretch you might say that Rubens' The Martyrdom of Saint Livinus shows a horse scratching its behind on a tree. [See Appendix 6-Philippe de Champaigne, Presentation in the Temple, and Appendix 7-Peter Paul Rubens, The Martyrdom of St Livinus]

In short, intertextual analysis shows the transformations that the myth of Daedalus and Icarus has undergone, from a story in Ovid, via Bruegel, via a restorer's alterations, and possibly also via John Singer Sargent's painting, to Auden's poem.

And another thing has become clear: The Landscape with the Fall of Icarus is a mythological painting, but it is associated in Auden with a number of Christian scenes and/or stories: the census, the massacre of the innocents, the presentation in the temple. These influences on Auden's poem are not, however, sufficient grounds for authoritative conclusions on how it should be interpreted. Although it is an illusion to think that Auden's poem has any univocal meaning that can be identified with certainty through research, this is not to say we cannot move some way in that direction, by analysing structure and form.

\section{Structure and Form}

Musée des Beaux Arts is an example of free verse, a poem that does not conform to any existing verse form. It has traces of a sonnet, but where the two parts of a sonnet have eight and six lines, there are thirteen and eight here. Sonnets often have a contrast between octave and sextet: one part offers a specific 
event or observation, which is interpreted and placed in a wider context in the other part; the order in which this happens varies (Vestdijk 1969: 153154). ${ }^{3}$ This contrast also exists in our poem. It begins with a general statement-'about suffering they were never wrong, the Old Masters' - and it concludes with the observation of a specific painting, Bruegel's Icarus. The poem bears close resemblance to the spoken word; you can almost imagine how a guide taking you on a tour of the museum might begin by saying: 'about suffering they were never wrong, the Old Masters'. Closer analysis reveals a subtle shift (an inversion). Normally you would say 'the Old Masters were never wrong about suffering'. But the poem is not about the old masters, and Auden has used the principle, also found in papal encyclicals, that the first words of the text always reveal its subject (Fides et ratio, Populorum progressio), and the first sentence is constructed in such a way as to ensure that the most important words come first: this is a poem 'about suffering'.

Sonnets have a rather strict rhyme scheme, where the octave has two rhymes and the sextet two different rhymes, for instance ABBA ABBA CDC DCD or $A B A B A B A B C C D C C D$. But there are many different variants, for instance with four rhymes in the octave and three in the sextet (Vestdijk 1969: 147148). Auden's poem also has end rhyme, and this according to the following scheme: ABCADEDBFGFGE HHIJKKIJ. Of the twenty-one lines, twenty have end rhyme in pairs, but the pairs are distributed unevenly across the poem, with the result that the rhyme is less conspicuous. This effect is amplified because Auden has endeavoured to de-emphasise the rhyme. He uses two techniques to do this. First enjambment: he continues sentences beyond the end of the line into the next one, so that the stress on the rhyming word is reduced. One example is: 'how well they understood / Its human position'. Because the reader continues to read after 'understood', the stress on '-stood' is brief and light. He also applies stress shifts: in some cases Auden places a stressed word directly before the rhyming word. This also makes the rhyming word less conspicuous. An example is: 'They never forgot / That even the dreadful martyrdom must run its course'. Here, 'never' is stressed to such an extent that it diverts attention from 'forgot' (Vestdijk 1969: 90-100). The only final sound in Auden's poem that does not rhyme with another final sound is $\mathrm{C}$ ('place'): 'how it takes place / While someone else is eating'. 'Place' does, however, rhyme with 'aged'.

\section{Meaning}

According to Larrimore, Auden's Musée des Beaux Arts is about suffering, about how the world continues to turn even when the most dreadful tragedies take place. The world is indifferent and does not respond, or even turns 
its gaze the other way, as the shepherd does in Landscape with the Fall of Icarus. This must have struck Auden, or he would not have written a poem about it. We cannot know for certain why it affected him so much, but as Nemerov has suggested, it is possible that his experiences during the Sino-Japanese War played a role. Auden not only describes this situation, but he also depicts it, as it were, by using day-to-day language; the old masters understood this well, he says, even to the point that 'about suffering they were never wrong'.

And yet Auden suggests as early as in line 3 that there is more to be said about suffering: what the old masters understood about suffering was 'its' human 'position'. This added aspect is not immediately evident from Bruegel's paintings, Auden suggests: there, the children continue skating and the ships continue sailing. And he also explains why: for those who do not suffer, the suffering of those who do suffer is irrelevant. For the ploughman, it is important that the sun continues to shine. For the ship, it is important that it must still reach its destination, and the drowning of Icarus makes little difference. But there is more than the 'human position': a miraculous birth, awaited reverently, even passionately, by old people. This birth seems to tell us something about the position of suffering not with humankind, but "with God'. And for God human suffering is not indifferent. God has shared in this suffering and thus made it His own suffering, in the person of his Son, who came to earth through a miraculous birth. The fact that martyrdom is then mentioned confirms this suggestion. Martyrdom is not the same thing as being tortured: martyrdom is 'meaningful suffering', suffering as testimony to, and in communion with, Christ. That martyrdom means witnessing can also be seen from the fact that the Greek word from which our word 'martyr' is

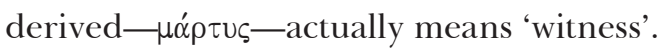

Ostensibly the miraculous birth has not changed much: the world continues to turn and the poem goes on. But in the meantime a 'hidden order' is present in the structure of the poem: an order that is hidden under the irregular rhyme scheme and the de-emphasising of rhyme. It is a hidden law, to use the title of another one of Auden's poems:

The Hidden Law

The Hidden Law does not deny

Our laws of probability,

But takes the atom and the star

And human beings as they are,

And answers nothing when we lie.

It is the only reason why

No government can codify,

And verbal definitions mar 
The Hidden Law.

Its utter patience will not try

To stop us if we want to die;

If we escape it in a car,

If we forget It in a bar,

These are the ways we're punished by

The Hidden Law.

This poem from 1940 is about a hidden law, a law that leaves the laws of nature intact and that will not stop us from dying. This law shares certain characteristics with God: it punishes, but from a basic attitude of tolerance, and at least sometimes the word that refers to it is capitalised. According to Anthony Hecht, Auden was subconsciously integrating Christian motives 'at a period of his life when he was at least unconscious of any Christian belief, so that the Hidden Law was, as far as we can, or he could, judge, truly hidden from him' (Hecht 1993: 463). Could this not also be the key to a number of things that we have observed in Musée des Beaux Arts? We know that Auden at this time was interested in the Christian faith, and that he eventually became a convert. Is it not likely that Auden was not only struck by the position of suffering with humankind, but was also fascinated by the position of suffering with God, references to which he found in the paintings of the Old Masters? A position that he tried, tentatively, to represent by referring to the Christian motives in those paintings, and to depict by concealing a strict order beneath the ordinariness of his language?

If we may interpret the poem in this way, all kinds of references to the birth, life, and death of Jesus become clear in its second stanza (from line 14 onwards). Bruegel's Icarus is here introduced as an example of the world which turns away from the dreadful martyrdom that has to take place. This is clear even from a surface reading of the poem. Once we focus on the hidden meaning of suffering, however, it becomes difficult not to think here of the prologue to the Gospel of St John, where Jesus appears as a witness ( $\epsilon$ i $\zeta$

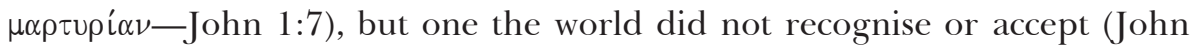
1:10-11). Instead, the world turned away from him. Jesus also died with a forsaken cry: 'My God, my God, why have You forsaken me?' (Matthew 27:46). Incarnation, suffering and death are regarded here as one continuing movement: Jesus' self-emptying began with the incarnation:

6 Who, being in the form of God, did not count equality with God something to be grasped.

7 But he emptied himself, taking the form of a slave, becoming as human beings are; and being in every way like a human being,

PERICHORESIS 14.2 (2016) 
8 he was humbler yet, even to accepting death, death on a cross (Jerusalem Bible) (cf. Sarot 2012).

By ordinary standards, Jesus' life also ended in failure, and this failure turned into victory only for His followers who came to the conclusion that Jesus' failure was their salvation. Viewed in this light, the fact that Icarus disappears into the water also acquires a deeper meaning: immersion into the waters of baptism in Christianity refers to dying with Christ, while rising out of the baptismal water refers to rising with Christ: 'By our baptism into his death we were buried with him, so that as Christ was raised from the dead by the Father's glorious power, we too should begin living a new life' (Romans 6:4). It is through baptism that Jesus' failure becomes relevant and even important to us. If we interpret the second stanza of the poem in a Christological way, the 'boy falling out of the sky' can also be understood to have a deeper sense as referring not only to Icarus, but also to the incarnation of Christ, which, being miraculous, is truly 'something amazing'. Once we read these lines in this way, we begin to understand why the ship that fails to notice this 'something amazing' is expensive and delicate: the Gospel often emphasises that there are people who 'look without seeing and listen without hearing or understanding' (Matthew 13:13; cf. Romans 11: 8-10), and that this group includes the rich, because they have other things on their minds (Matthew 19: 16-26, esp. 22, 24; cf. Matthew 6: 26-33), that is, they have 'somewhere [else] to get to'. In these lines, being blind to Icarus' disaster, being blind to the sufferings of those around us, and being blind to Christ, all become essentially the same thing. As Christians, we should, with Pope Francis, see 'in the poor ... the face of Christ who for our sake became poor' (tweet 22 Oct. 2015).

Once we have discovered how rich the second stanza of the poem is in references to the Christ event and to the salvation that results from it, it becomes clear that the poem can be seen as reflecting a stage on Auden's path towards conversion. The paintings he saw in the Museum of Fine Arts did not leave him unmoved; they made him sense a reality that he was unable to grasp completely, but which the words of his poem allowed him to reach for: a hidden Law.

This is therefore a poem of many transformations: an ancient myth that Bruegel transformed into a painting, whose meaning changed again at the hands of an inept restorer, a meaning taken up and highlighted by Auden, but also placed by him in a new, Christian perspective, in which the human position of suffering is contrasted with the silent Law. This ultimately changes not only the meaning of the fall of Icarus, but it also changes Auden himself. This poem is a poem on the path to conversion.

For the systematic theologian, it contains a lesson in humility. In this poem, Auden describes not how well-developed theological theories influenced him, 
but how artistic representations of the Christian faith moved him. As a second-order reflection on what happens in a conversion process, theology has its role to play, but ultimately first-order expressions-including those by artists-are more important. For the attentive reader, Auden's poem contains deep insight into the Christian faith, which holds together cross and resurrection, failure and victory, the suffering of Jesus and the suffering of the poor of our world. Not only does it teach us theologians humility, it also reassures us that everything does not depend on us. This, too, is an important transformative insight.

\section{Concluding Remarks: Transformative Poetry and Its Role in Catholic Theology}

These concluding remarks are concerned not only with the above analysis of Auden, but also with the preceding articles on transformative poetry and its role in Catholic theology: Archibald van Wieringen's article on Psalm 2, Paul van Geest's on Augustine's Psalm against the Donatists, Henk Schoot's on Thomas Aquinas' Adoro te devote, Frank Bosman's on the Heliand, and WillemMarie Speelman's on Francis of Assisi's Canticle of Brother Sun.

The topic of this special issue of Perichoresis is 'Transformative Poetry: Its Role in Catholic Theology'. Is there a reason to suppose that Catholic theology has a different relationship to poetry than, e.g., Protestant theology? I think there is.

You can say in English that someone is 'a person of catholic tastes.' This is said about people with wide-ranging or comprehensive interests. In a similar way, I would like to suggest that Catholic theology has more wide-ranging tastes than its Protestant counterpart. Let me explain what I mean. There is a strong current in Protestant theology that argues that we should focus on Scripture as theology's one and only source; arguably, one of the five solas addresses this issue: sola Scriptura. Karl Barth was the most outspoken protagonist of this position in the twentieth century. Barth argued against any form of both/and theology: revelation and reason, revelation and religious consciousness, revelation and ethos of culture, revelation and creation, etc. (Barth 1986: 70). Barth regarded all of these both/and positions as transgressions of the first commandment, to have no other gods beside YHWH. In our century, D. Stephen Long has explicitly supported Barth by claiming that 'there is still good reason to be worried about the "copulative and" within Catholicism' (Long 2001: 57).

By contrast, ever since Melchior Cano's De locis theologicis, Catholic theology has consciously drawn on a wide variety of sources. Cano distinguished between ten sources that could be used in theology: (1) Holy Scripture, (2) the traditions of Christ and the apostles, (3) the universal Church, (4) synods and councils, (5) the Roman Church and its bishop, (6) the church fathers, 
(7) the scholastic theologians, (8) the value of natural reason as manifested in science, (9) the authority of philosophers, and (10) the authority of history. Most theologians do not regard this enumeration as limitative, and admit other sources as well. Jared Wicks explains:

The main trait of theology in the style of Cano is the breadth and number of the resources, what we can call the true catholicity of the bases on which such work draws. This theology may lack the concentration practiced and recommended by Luther, but it often impresses by the variety of fields in which it moves. [...] A contemporary doctrine of the loci, or sources, will introduce areas not found in Cano, such as the witness of the liturgy, the meaning that breaks forth from lives outstanding in holiness, and the experience of regional and local churches (Wicks 2009: 15-16).

It may well be argued that Christian poetry as such can also function as a locus. If we look at the poetry discussed in this special issue, almost all of it overlaps with other sources mentioned by Cano: the Bible (Psalm 2), the Fathers (Augustine), the scholastic theologians (Aquinas), the saints (Francis), the tradition (Heliand). Auden is the obvious exception. Here, more than in the other cases, there is the danger that D. Stephen Long emphatically warns against: it may 'tempt $[\ldots]$ us to tolerate competing allegiances without recognizing we are doing so' (Long 2001: 58). It should be very clear, then, that these other loci should never be seen as rivals of Scripture that carry equal authority, but that they are interpreted in line with Scripture and the Catholic tradition. I hope it is clear that this has in fact been the case in the preceding contributions.

This does not imply, of course, that the poems we have discussed cannot lead to novel insights. Even though these insights will not generally be revolutionary, we must hope that they will lead to a deeper understanding of our own tradition, and thereby also of what we believe. The poems that we have discussed are examples of transformative poetry: they describe or express the processes of transformation that believers undergo both when they begin to believe and as their faith journey progresses. If the life of the believer can be regarded as a journey of growth in faith, these poems articulate stages in that growth. In some cases, the poems are about the transformation of individual believers. Auden, for instance, was struck by pictures in a Brussels museum that led him to consider suffering: the suffering of Icarus, of war victims and other contemporaries, the suffering of Christ. And even though this religious layer of his poem remains implicit and is accessible only if we read between the lines, the religious claims he makes testify to a mature insight into the Christian faith. In a sense, the poem can be compared to the Chronicles of Narnia by C. S. Lewis (Lewis 2001): children who admire the lion Aslan will be brought closer to Christ, even when they are not aware that Aslan is Christ 
(Lewis 1985: 52-53). In the same way, those who reject the 'expensive delicate ship' that 'had somewhere to get to' and therefore ignored the drowning Icarus, are brought closer to Christ.

Other poems, while they originally articulated the transformation of an individual, subsequently became expressions of the piety of larger communities. This was the case with Aquinas' Adoro te devote, which-as Henk Schoot shows-originated as a prayer written for private use but came to be used in community adoration of the Eucharist. It also applies to St Francis's Canticle of Brother Sun, which originated as an individual song of praise, albeit one in which Francis calls on the whole of creation to offer praise with him, and which many have subsequently made their own. Still more recently, it has become a source of inspiration for the ecological spirituality of the Catholic Church as a whole.

Psalm 2, on the other hand, does not appear ever to have been the expression of an individual transformation; instead it is an invitation to the textimmanent reader to undergo such a transformation, an invitation that the Christian community has understood as being addressed to itself through Jesus Christ's resurrection or incarnation. Something similar applies to Augustine's Psalm against the Donatists: this is a parenetic work, intended to be learned by heart, which tries to arm Christians against the dangers of Donatism. That it is aimed at a group rather than an individual can also be seen from its beginning: 'Let us inquire without error'. For a theoretical underpinning of Augustine's reliance on the transformative power of poetry, Paul van Geest refers to his Enarrationes in Psalmos. The Heliand also is a classic example of a poem not intended as the most individual expression of the most individual emotion. As Frank Bosman shows, it was probably commissioned by Louis the Pious, and it intended to translate the Gospel into the concepts of the Frankish culture of those days. In order to achieve the intended transformation of believers, the Gospel must be inculturated. There is a parallel here, as Bosman demonstrates, with the incarnation of Christ: in order to enable the Gospel message to become a principle that animates and informs a culture, it must become incarnate in that culture. In order to become successful as a transformative poem, the Heliand must first transform the Gospel. Bosman shows how it does this by analysing the Lord's Prayer.

Perhaps none of the prayers discussed in this special issue is more explicitly transformative than Aquinas' Adoro te devote. Aquinas prays: 'Make me believe, make me hope, give me love, give me life, make me savour, purify me, quench my thirst for you.' Henk Schoot has shown how the poem's form reflects its content: a prayer for ongoing transformation that corresponds to the transformation of bread and wine. Here we come very close to what Catholicism views as the essence of transformation: by eating the Body of Christ, Christians become the Body of Christ and participate in the Paschal mystery.

PERICHORESIS 14.2 (2016) 
In other words, they suffer, die and rise with Christ. For Christians, the "boy falling out of the sky' is 'something amazing' indeed, and His failure on the cross is an important failure, a failure that God himself transforms into the supreme victory. Through baptism and the Eucharist, we are taken up into His life's story and we will-in Aquinas' terms-always live through Him and savour His sweetness. ${ }^{4}$

\section{Bibliography}

Anonymous (2016) Landscape with the Fall of Icarus. Wikipedia. www.en.wikipedia.org/wiki/Landscape_with_the_Fall_of_Icarus [accessed on 30 May 2016].

Auden WH (1939) Journey to a War. New York, NY: Random House.

Auden WH (2002) The Means of Grace: Review of The Nature and Destiny of Man by Reinhold Niebuhr. In The Complete Works of W. H. Auden: Prose, volume 2: 1939-1948. Princeton, NJ: Princeton University Press, pp. 131134.

Auden WH (1979) Selected Poems. London: Faber \& Faber.

Barth K (1986) The First Commandment as an Axiom of Theology. In Barth K \& Rumscheidt M (ed) The Way of Theology in Karl Barth: Essays and Comments. Allison Park, PA: Pickwick Publications, pages 63-78.

Bruegel the Elder P (year unknown) Landscape with the Fall of Icarus [oil on canvas] Brussels: Musées Royaux des Beaux-Arts. Picture taken from https://upload.wikimedia.org/wikipedia/commons/c/c2/Pieter_Bruegel_de_Oude_-_De_val_van_Icarus.jpg.

Bruegel the Elder P (year unknown), The Massacre of the Innocents [oil on wood] Brussels: Musées Royaux des Beaux-Arts. The picture was taken from https://en.wikipedia.org/wiki/Massacre_of_the_Innocents\#/media/File:Pieter_Bruegel_the_Elder_-_Massacre_of_the_Innocents_-_Google_Art_Project.jpg.

Bruegel the Elder P (1610) The Census at Bethlehem [oil on wood] Brussels: Musées Royaux des Beaux-Arts. Picture taken from https://commons.wikimedia.org/wiki/File:Pieter_Brueghel_de_Jonge_(1564of65-1638)_-_De_volkstelling_te_Bethlehem_(1610)_-_KMSK_Brussel_25-02-2011_12-1745.jpg.

Bruegel the Elder P (copy after) (year unknown). Landscape with the Fall of Icarus [oil on wood] Brussels: Musée van Buuren. Picture taken from https://ceroart.revues.org/docannexe/image/2953/img-2.jpg. Utrecht as well as Johan de Weerd and Professor Willem J. van Asselt $\dagger$ for conversations regarding the insights expressed in this paper, which also benefited greatly from a discussion in the research group 'Initiation and Mystagogy in the Christian Tradition' whose members I would like thank wholeheartedly. 
Cano M (1563) De locis theologicis. Salmanticae: Mathias Gastius.

Davenport-Hines R (2004) Auden's Life and Character. In Smith S (ed) The Cambridge Companion to W. H. Auden. Cambridge: Cambridge University Press, pp. 15-24.

De Champaigne P (ca. 1648) Presentation in the Temple [oil on canvas] Brussels: Musées Royaux des Beaux-Arts. Picture taken from http://www.wga.hu/html_m/c/champaig/philippe/presenta.html.

De Geest J (2006) 500 Chefs-d'œuvre de l'art Belge. Brussels: Racine.

De Volder B (n.d.) Beeldgedichten www.dagvandepoezie.be/beel-dgedichten.doc [accessed on 15 May 2016)].

Epstein R (2016) The Empty Brain. In Aeon Essays, https://aeon.co/essays/your-brain-does-not-process-information-and-it-is-not-a-computer [accessed on 22 May 2016)].

Hecht A (1993) The Hidden Law: The Poetry of W. H. Auden. Cambridge, MA: Harvard University Press.

Jack A (2012) The Bible and Literature. London: SCM Press.

Jenkins N (2004) Auden in America. In Smith S (ed) The Cambridge Companion to W. H. Auden. Cambridge: Cambridge University Press, pp. 39-54.

Kinney AF (1963) Auden, Bruegel, and 'Musée des Beaux Arts'. College English 24(7): 529-531.

Kirsch A (2005) Auden and Christianity. New Haven, CT: Yale University Press. Larrimore M (2001) The Problem of Evil: A Reader. Oxford: Blackwell.

Lewis CS (1985) Letters to Children. New York, NY: HarperCollins.

Lewis CS (2001) The Chronicles of Narnia. New York, NY: HarperCollins.

Long DS (2001) The Goodness of God: Theology, Church, and the Social Order. Grand Rapids, MI: Brazos Press.

McCouat P (2015) Bruegel's Icarus and the perils of flight. Journal of Art in Society, www.artinsociety.com [accessed on 22 May 2016)].

Mendelson E (1981) Early Auden. New York, NY: Viking.

Mendelson E (2004) The European Auden. In Smith S (ed) The Cambridge Companion to W. H. Auden. Cambridge: Cambridge University Press, pp. 55-67.

Nemerov A (2005) The Flight of Form: Auden, Bruegel, and the Turn to Abstraction in the 1940s. Critical Inquiry 31(4): 780-810.

Ovid (n.d.) Metamorphoses.

Reeves G (2004) Auden and Religion. In Smith S (ed) The Cambridge Companion to W. H. Auden. Cambridge: Cambridge University Press, pp. 188-199.

Rubens PP (1633) The Martyrdom of St Livinus [oil on canvas] Brussels: Musées Royaux des Beaux-Arts. Picture taken from https://nl.wikipedia.org/wiki/Livinus_van_Gent\#/media/File:The_Martyrdom_of_St_Livinus_by_Rubens.jpg.

Robert-Jones P (1974) Bruegel la Chute d'Icare. Fribourg: Office du Livre.

PERICHORESIS 14.2 (2016) 
Sargent JS (1918) Crashed Aeroplane [watercolour, pencil, and gouache] London: Imperial War Museum. Picture taken from: https://www.artrenewal.orgpagesartwork/pages/artwork.php?artworkid $=13701$.

Sarot M (2012) Beyond Kenoticism: Why the Suffering God had to Become Man. Dutch Reformed Theological Journal 52 (Supplement): 100-112.

Smith S (2004) Introduction. In Smith S (ed) The Cambridge Companion to W. H. Auden. Cambridge: Cambridge University Press, pp. 1-14.

Van Roy L (n.d.) Icarus of de bewegingen van een geest, ludovan-roy.tripod.com/icarus.htm [accessed on 30 May 2016)].

Vestdijk S (1969) De glanzende Kiemcel: Beschouwingen over poëzie. Amsterdam: De Driehoek, 4th impression.

Wicks J (2009) Doing Theology. New York, NY: Paulist Press. 



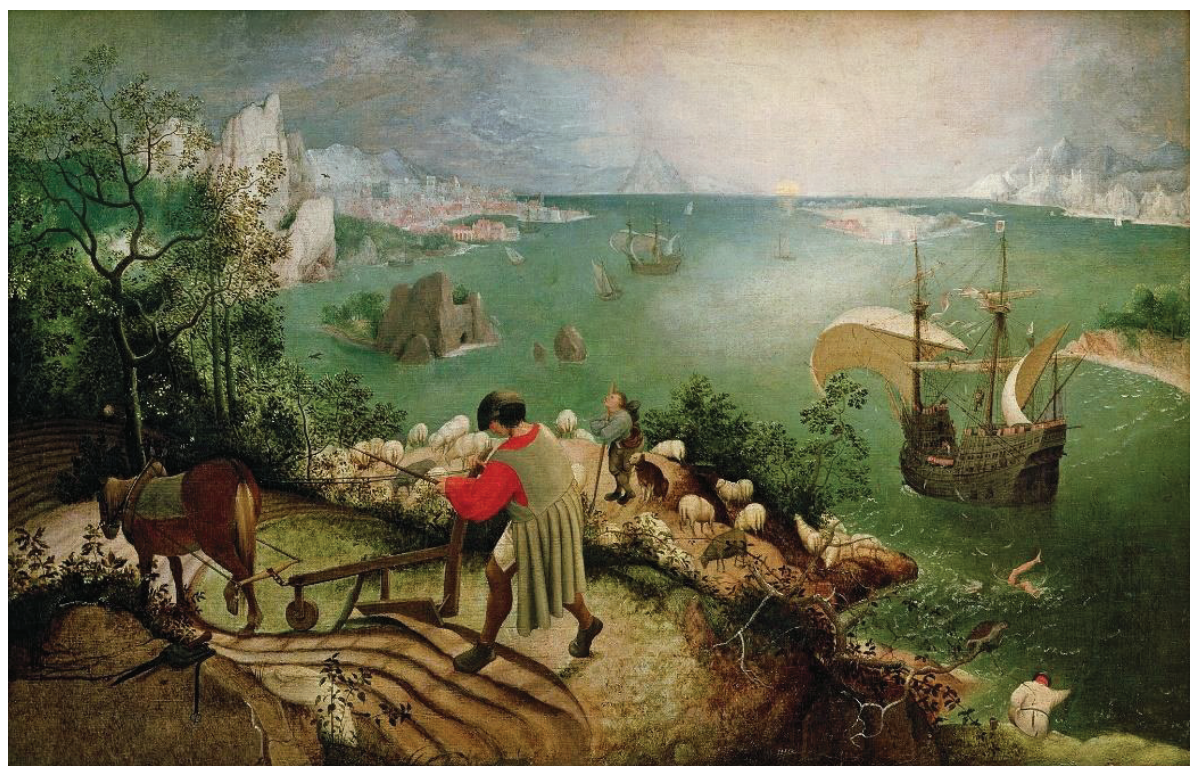

Appendix 1-Bruegel, Landscape with the Fall of Icarus

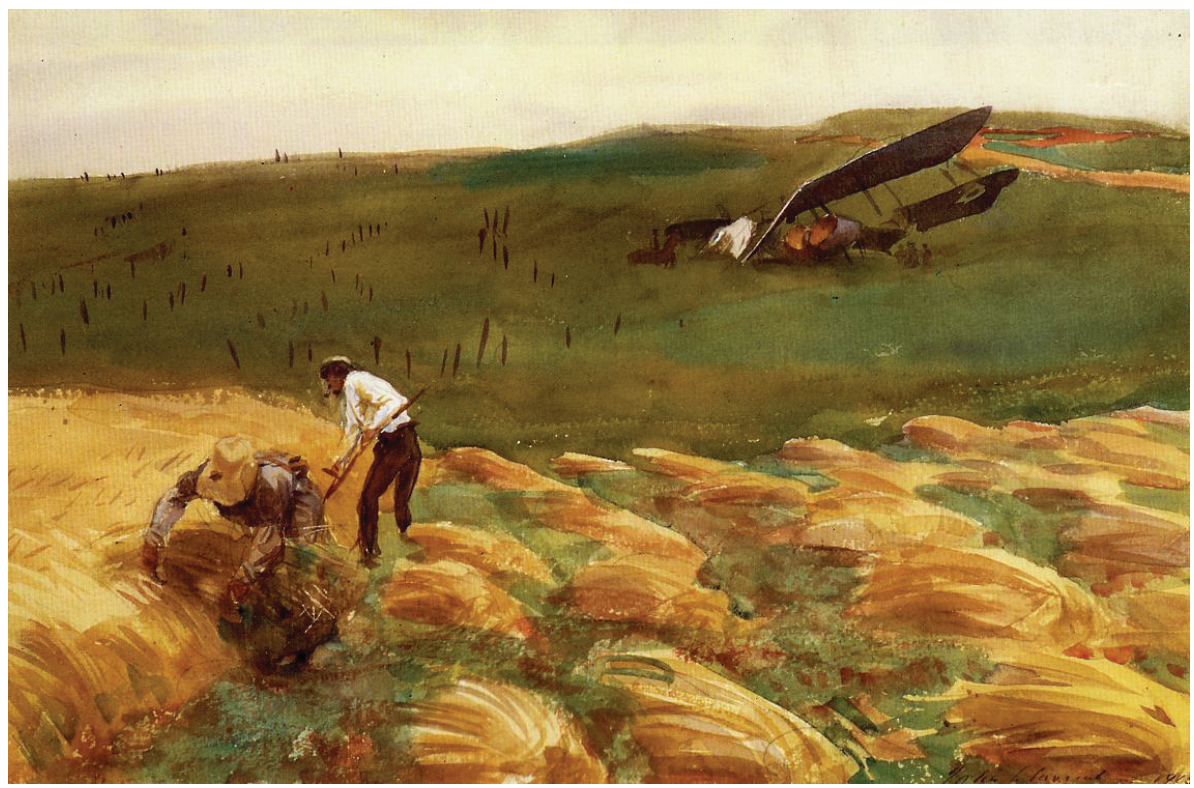

Appendix 2-John Singer Sargent, Crashed Aeroplane 


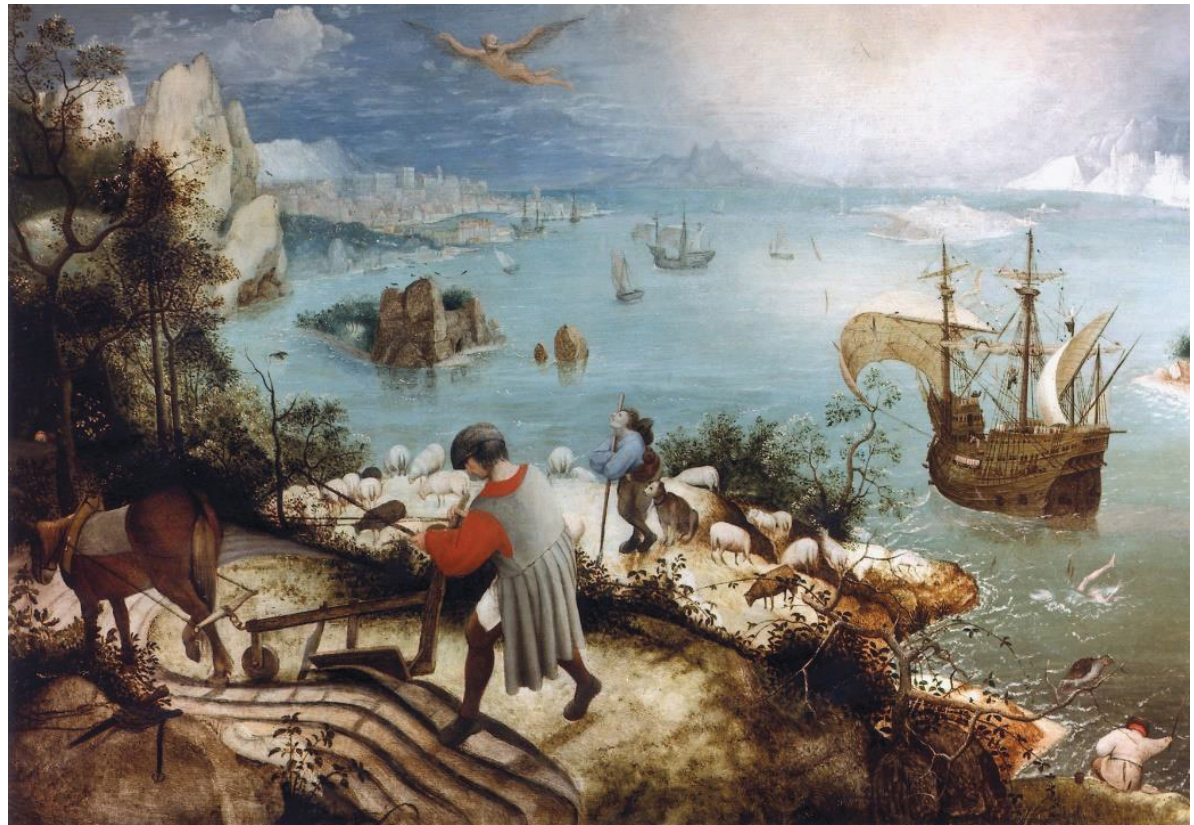

Appendix 3-Pieter Bruegel, Landscape with the Fall of Icarus (Musée Van Buuren)

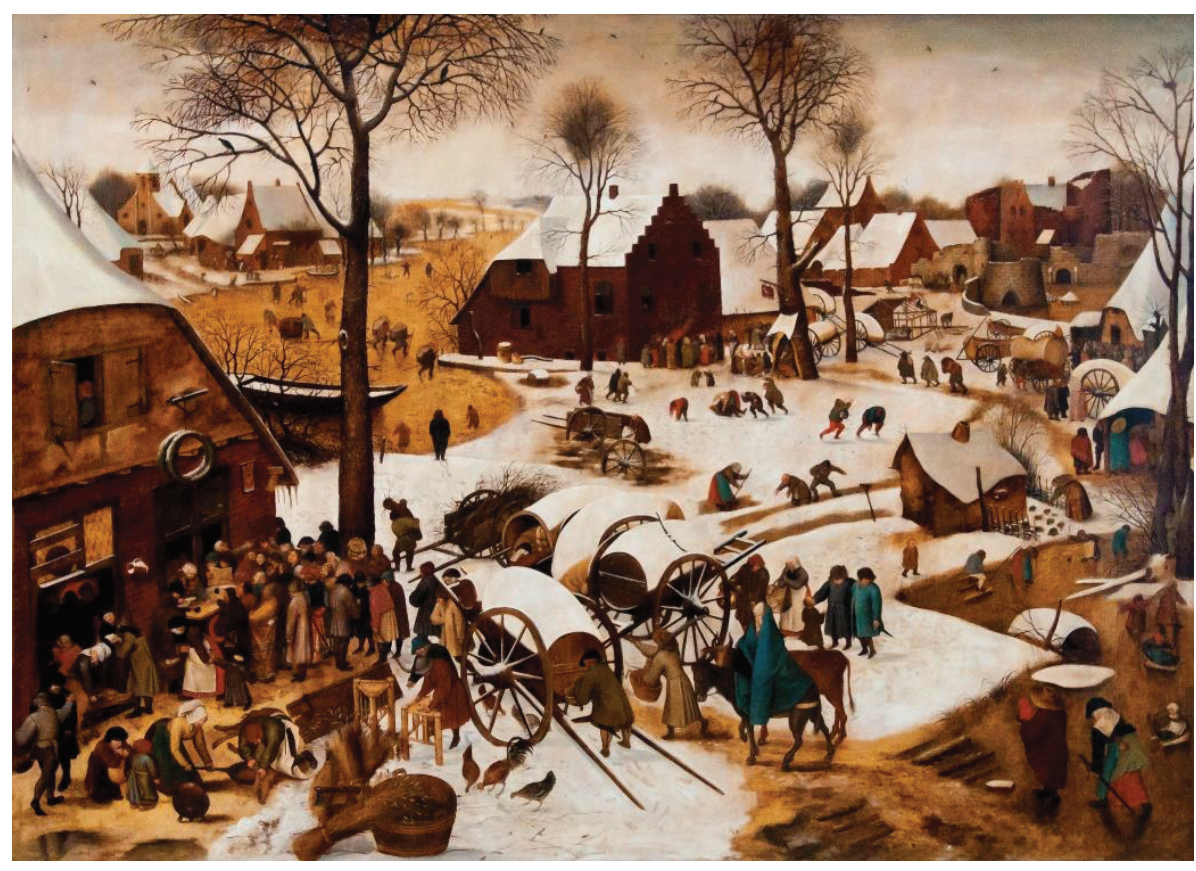

Appendix 4-Pieter Bruegel, The Census at Bethlehem

PERICHORESIS 14.2 (2016) 


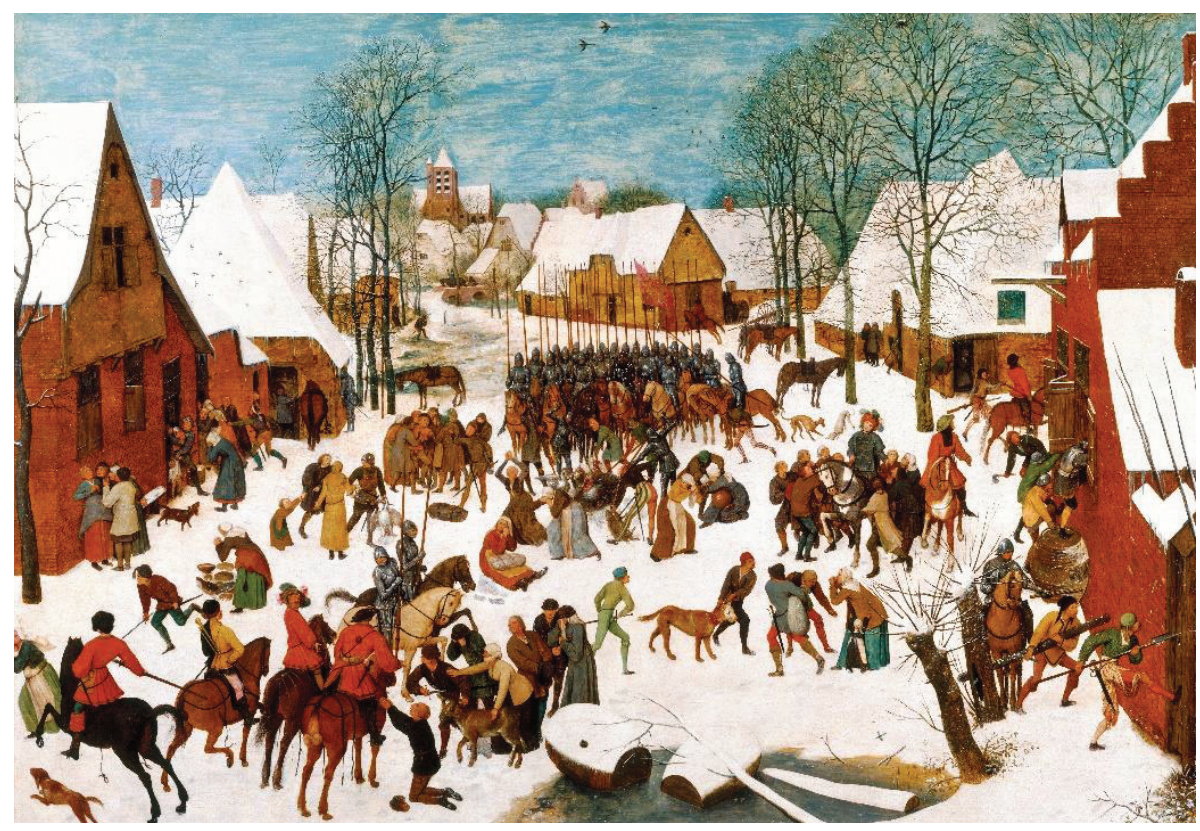

Appendix 5-Bruegel, The Massacre of the Innocents

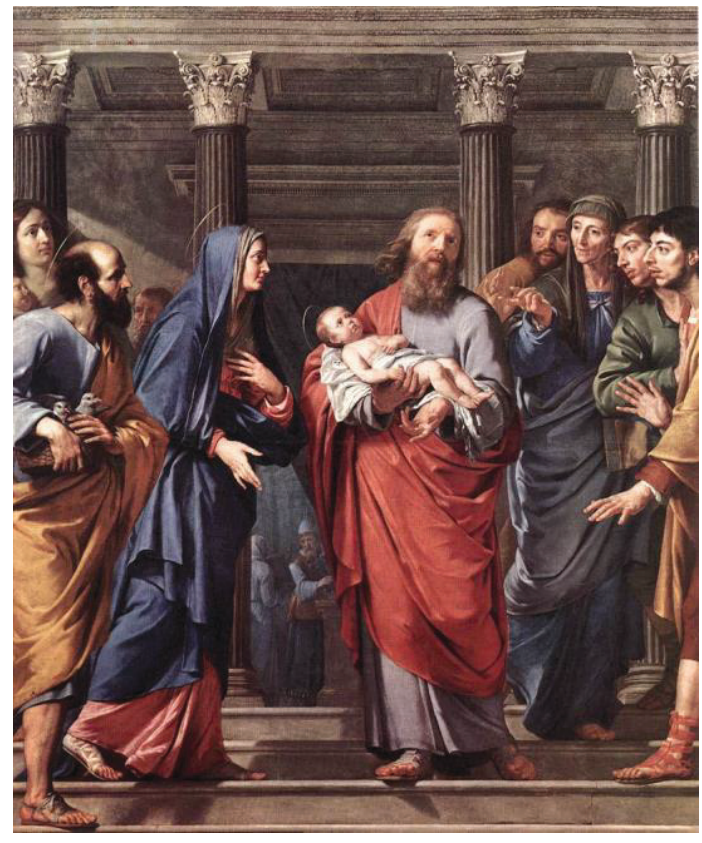

Appendix 6-Philippe de Champaigne, Presentation in the Temple 


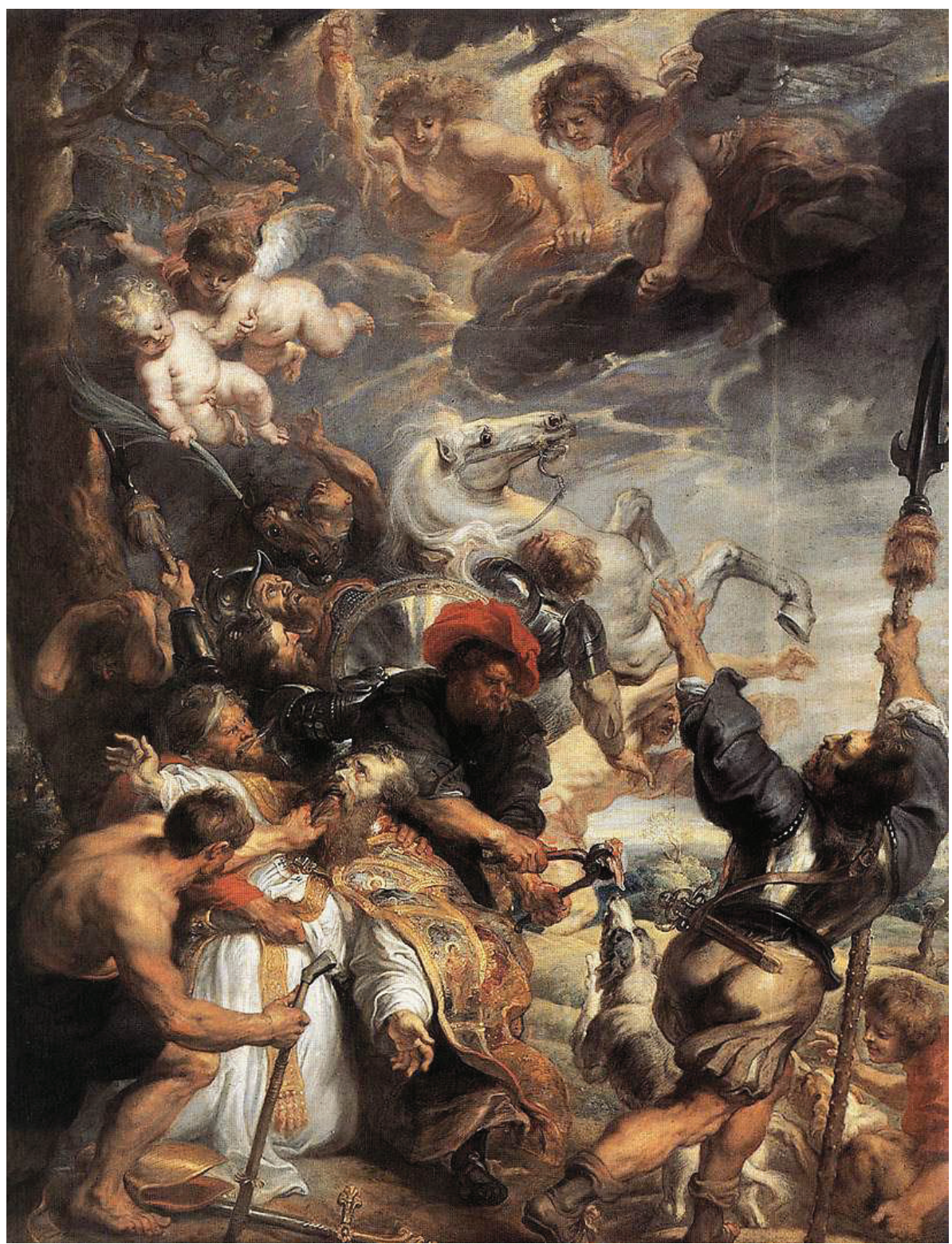

Appendix 7-Peter Paul Rubens, The Martyrdom of St Livinus 